\title{
The Research on Democratic Quality of University Students
}

\section{LiuFangfang $^{1}$}

\author{
${ }^{1}$ School of Marxism, JiangSu Univsity, ZhenJiang, JiangSu, China
}

\begin{abstract}
Democracy is one of the hallmarks of human civilization and a landmark issue in the process of achieving the great rejuvenation of the Chinese nation. Improving the quality of all democratic awareness has a very important strategic significance on the development of socialist democratic politics and the establishment of socialist political civilization. Being the future builders and successors of the socialist cause with Chinese characteristics, college students are continuing momentum of social development and a significant group in the process of advancing the construction of socialist democratic politics which can not be ignored. The aim of this research is to strengthen the importance of democratic construction of student organizations and building a democratic living environment so as to help them to get access to experience of democratic life, thus practical improvement of contemporary college students' democratic quality and ability can be achieved.
\end{abstract}

Keywords: University Students, Democratic Consciousness, Socialist Construction

\section{Introduction}

What do we know about democracy? Acemoglu and Robinson (2006)entitled "What do we know about democracy?": democracy is "... the institutional arrangement for arriving at political decisions in which individuals acquire the power to decide by means of a competitive struggle for the people's vote (p. 48).Education is the civilization of a human being and aims to impact the behavior of individuals (Detjen 2007: 3). According to Buhl, educating young people to become members of society, who actively participate in the shaping of the political environment is a crucial step in the context of political socialization (Buhl 2003:16). How to reach the account of the two conceptions and make links is the process in which the government and authorities are focusing on in China, so called the political socialization. The concept of political socialization is a long historical educating process for the young to become equal citizens of the future political ruling. Democracy is also used as a standard to measure the politic improvements of the other countries and this makes it a very popular concept (Apple \& Beane, 2011).How to proceed the civic education among young people to make good preparations for the future political development and achieve a harmonious democratic life is a question worthy of our attention. However, what is the definition of civic education, a previous study regarding college access states that the notion of "civic education" as a generic term for intentional political learning in educational institutions which is used and is not limited to those forms of political learning (Sander 2002: 12). Democracy education or democratic education, both of these two different conceptions in educational institutes play a significant role in building a democratic society. (Bakir, 2012) Both of these two teaching modes are mostly understood as informing individuals about democracy (Kincal\&Isik, 2003) and aimed to make sense of democratic awareness. Particularly in China, Whether the level of contemporary college students' democratic quality can be improved or not, relates to the stable development of China's economy and the constant democratic construction and socialism progress. Historically constructed views that though the $19^{\text {th }}$ and $20^{\text {th }}$, many societies in China and abroad have been searching ways of being liberal and democratic knowledge used in education, however, little performance is achieved as a result (James, Jenks, \& Prout, 1998). Gutmann and Thompson(as cited in Englund,2000)mentioned that in order to make the democracy more deliberate, democratic governments are getting importance in terms of allowing people get their rights necessary for having a place in the society (Dagan, 2004).Democratization and legislation are two important parts of political restructuring started as early as 1980s. The past 30 years has witnessed the efforts made by the Chinese Communist Party on the solutions of the problems emerged in the reforming progress, delightedly, so a great influence as it has on the Chinese Political

This article is published under the terms of the Creative Commons Attribution License 4.0

Author(s) retain the copyright of this article. Publication rights with Alkhaer Publications.

Published at: http://www.ijsciences.com/pub/issue/2017-06/

DOI: 10.18483/ijSci.1309; Online ISSN: 2305-3925; Print ISSN: 2410-4477 
environment that much socialist democratic advances are achieved today. Various historical conflicts at home and abroad have provided evidence that unless the democracy is adopted as a lifestyle and fostered by the democratic practice, it would be impossible for it to develop as a ruling system. The democracy is formed only through the interactions between the ruling system, the philosophy of life and the lifestyle (Gu“rsimsek \& Go"regenli, 2004: 78). Democratic Education, as a form of political propaganda in China for the government, of course, has great significance in adopting the democracy as a lifestyle and a philosophy of life. By means of this socialization process, the democracy is not only a model of governing system, but a deterministic factor to motivate people who have been educated in this political system to put the political regulations into the social life. This research has the purpose to breakthrough the development of theoretical analyses of the caring higher education teacher from the monotonous teachers' perspectives themselves, but turns to a wider field to identify and explore the factors that affect the democratic quality in higher education. A reputational review and investigation was conducted to report the interaction between the educational conditions and democracy, and the aim of this research is not to point out the severe inequity and injustice existed in Chinese governmental situation, nor was it the intention of the study to evaluate the impact of care on students' democracy learning outcomes, but to illustrate the objective issues that should be perceived in terms of the official and teachers which militate against the social development.

\section{Problem statement}

To develop socialist democratic politics is the required element to promote the modernization of national governance system and governance ability, in which the young generation played one of the unneglected key roles. This paper aims to breakthrough the analyses in terms of educators and administrators and turned to the students, the subject position as well as the leading role in the future teaching process. Furthermore, the author has evolved the traditional mode of thinking and research method and attempts to discuss in the combination of Marx's thought about human and students' experience of democratic life so as to develop habits of democracy and grow into their own values. It also creates the focus on the importance of democratic education and administration based on the current situation today.

\section{Methodology}

\subsection{The participants}

The research includes 440 student teachers in total who studied at JiangSu University during 2015-2016 academic year.

\subsection{Research objectives:}

- Identify the positive achievements of democratic construction of university students' organizations.

- The existing problems in the democratic construction of university student organizations

- The actual approaches to improving the democratic quality of the contemporary university students

\subsection{Research questions:}

What is significant for this research is to reach the analyses of these questions:

- What is democracy?

- What is democratic education and democracy education?

- What's the current situation of democratic education in universities?

- What's the role of a democratic environment built on campus played in student democratic education?

- What're the varieties of teaching methods and information instruments used in the modern democratic education life?

- How can we promote the democratic process based on the hi-tech information era?

\subsection{Significance of the research}

This research has put forward new requirements for the teaching institutes in order to create an awareness of democracy for all walks of life based on the current educational situation. Because of the lack of cultivation of democratic participation consciousness both in Theoretical guidance and practical implements, this paper aims to develop a specific analysis on measures of democratic quality improvements for university students.

\section{Findings}

4.1. Positive achievements of democratic construction of university students

In general, a majority of students get access to the knowledge of democracy by the transmit of different channels, such as social teaching and every other process involved in schooling, Englund, 2006; Leppard, 1993; Peterson, 2009) the democratic consciousness acquired from which is shaped in the tendency of being much more rational and mature. On the basis of the situation in our country, the legal security system plays a crucial role in the success of democratization process (Deuchar, 2003), as is gradually realized among the young generation. Therefore, students in today's era hope to exercise their democratic rights on affairs of class leaders election and Party member selection.

4.1.1 Constant increasing consciousness of political 
participation

With the development of university democratic construction, an increasing number of students have paid more attention on the safeguard of democratic rights. Not only do they present a positive participating enthusiasm on election of class representatives, scholarship evaluation and honorary title, but also emerges an increasing interests on the national political issues related to law and democracy. In the case of this study, as an example, the first interview was subtitled 'On being democratic in universities', and sample questions included:

- Whether it is important to participate in departmental meeting and school issues?

- Do you personally pay attention on the great events or policies in China? How?

Table1: whether to participate in departmental meeting and school issues

\begin{tabular}{lllll}
\hline \multicolumn{1}{c}{ Issues } & numbers & proportion & valid proportion & $\begin{array}{l}\text { Cumulative } \\
\text { percentages }\end{array}$ \\
\hline Yes & 251 & 55.8 & 55.8 & 55.8 \\
no & 189 & 41.9 & 41.9 & 97.7 \\
unclear & 10 & 2.2 & 2.2 & 99.9 \\
In total & 451 & 99.9 & 100.0 & 100.0 \\
missing value & 1 & 1 & 0.1 & \\
Total value & 451 & 100.0 & & \\
\hline
\end{tabular}

Issues: whether to participate in departmental meeting and school

Table2: attention on the great events or policies in China

\begin{tabular}{lllll}
\hline \multicolumn{1}{c}{ Issue } & \multicolumn{1}{c}{ numbers } & proportion & Valid proportion & $\begin{array}{c}\text { Cumulative } \\
\text { percentages }\end{array}$ \\
& & & & 57.2 \\
often & 451 & 57.2 & 57.2 & 94.0 \\
sometimes & 291 & 36.8 & 36.8 & 98.6 \\
Seldom & 36 & 4.6 & 4.6 & 99.9 \\
never & 11 & 1.3 & 1.3 & 99.9 \\
In total & 789 & 100.0 & 100.0 & \\
Missing value & 2 & 0.1 & 0.1 & \\
Total value & 789 & 100.0 & & \\
\hline
\end{tabular}

Issue: attention on the great events or policies in China

According to the table1, the percentage of the students who claimed a necessity

to participate in the major decisions of the school was above 57.2\%,much higher than the opposite opinions(those who claims no necessities accounts for only $41.9 \%$ ), which suggests more than half of the respondents have the awareness of their democratic rights on school decisions. What's more, we can also find that students' interests in current affairs are greatly motivated. According to table $2,57.2 \%$ of the students investigated have presented their interests on great events or policies in China while the less attention on important issues just occupies $36.8 \%$ of the final result. (Those seldom give attention or show no care about politics just takes up 5\%)

When comes to the reason about the result above, it can be accepted as the world is becoming smaller because of the fast spread of the Internet. (Starkey, 2005 , p.299). Particularly in recent years, there has been growing approval in the impact of communication technologies such as net-meeting,
We-chat and other democratic facilities that enable individuals to reach information of social, political and economical development (Tsai, Lin, \& Tsai, 2001).On basis of this faster and easier information, Giroux and McLaren stated that (as cited in Sisman, Gunes \& Donmez, 2010) an interactive setting people today have more opportunities to share their opinions, join political discussions, and express their feelings or ideas freely (Scott and O'Sullivan , 2000). Therefore, it is apparent to observe the positive attitudes of an individual towards the democratic participation.

4.1.2 Rationality of the democratic supervision

According to the survey, the growth of awareness of democratic participation facilitates to the development of independence and rights safeguarding. Business Unsatisfied with the passive accept -ion of education and management, university students are critical of the fact that they were not invited to participate in class meetings or any other forum with decision-making powers (Schou, 20 01) concerning their own interests. On the contrary, They 
aim to be a protagonist character seeking for the establishment of an operational supervisory mechanism or effective approaches to democratic rights. Thanks to the new information instruments, such as the Internet, BBS, the E-mail, and other electronic election and electronic voting system which provide variable possibilities for people to get access to the decision-making of public affairs and protect their values when democratic rights are infringed (Rainer \&Guyton, 1999: 122). For example, during the graduate period, when canvassing or gifts are found in the class election or class assessment affairs, 49.8 percent of students choose to reflect to the teacher and president and 48.1 percent of them prefer to vent grievances in other ways rather than passively exit any other class activities .Therefore, one conclusion can be reached----When democratic rights being infringed, approximately half of them choose to protect, which demonstrates the rationality of the democratic supervision.

4.1.3 University students' confidence in the socialist democratic construction

The contemporary students hold a positive view towards the current socialist democratization progress. A majority of them are content with the achievements obtained from the 30 years' political restructuring in spite of the room for improvement. Because of the strong sense of legislation, they argue for rule of law and against the rule of man; they advocate equity and fight against privilege. In particular ,the recent international situation have greatly motivated the sense of national pride and patriotic feeling of the young generation, which encourages them to show more concern for the national affairs as well as the self-management awareness of the association affairs. In a word, the mainstream value of the young generation is positive. They believe that the Chinese government has devoted much to provide the right of education, communication, cooperation and other human rights for a democratic life and more citizens will be benefited from the socialist construction in future.

4.2 The existing problems in the democratic construction of university students

\subsubsection{Problems existed in terms of school management}

In terms of the school management, a democratic atmosphere with the students' participation in the policy decisions hasn't formed. Karaman-Kepenekci (2003) expresses democratic education as the education through which the principles and rules of democracy and human rights are learned by experience. Though the democratic consciousness of the university students is generally motivated and tends to be more reasonable, the insufficient applied implication and lack of theoretical guidance to some extent have a negative effect on the young's world outlook. On the one hand, the teachers were reluctant to get involved in teaching about controversial views and one of the most common ways that teachers thought is to provide opportunities for self-expression and open debate by students that help them to find their own voice in a safe and flexible classroom environment. (Ten Dam, Geijsel, Reumerman, \& Ledoux, 2011, Ten Dam \& Volman, 2007). On the other hand, the students today have a strong desire for getting engaged in the departmental meetings or any other decision-making powers concerning their courses or interests. Most universities at home have paid inordinate attention on the protection of students' democratic rights, especially the stress on the students' positive role played on teaching quality supervision or courses assessment. However, considering the campus stability, funds shortage and other objective ingredients, numerous educational institutes have no actual implementation of the new democratic management.

\subsubsection{Problems existed in terms of the students}

In terms of the students, the voice and their democratic aspiration are limited to the educational mode of centralization system. According to table 3 , it is obviously to find that decisions made by the principals in organizations or school departments take the biggest share of the total value. (62.7\%),despite the facts that they propose to fulfill their demands in relation to their own interests but little are adopted finally. meanwhile, it also results that $31.7 \%$ percentage of the statistical respondents also prefer a decision made by their teachers instead of themselves. From the data, it is apparent to see that the collective decisions of the students are generally represented by a small number of people. In another study at hand, the interviews were initially asked 'Have you ever participated in the decision-making of the school affairs?' One of the students noted that 'I don't know student representatives shall have the right to participate in the school administration decisions'. The same answers of the interviews account for $52.0 \%$ percent of the total data. The data of another facts 'I don't know if the student representatives can get access to the executive affairs through various channels' accounts for $44.4 \%$ percent. The above data indicates that over half of students have no awareness of their rights in the school democratic management process. Furthermore, restricted to the present policy decision institutions and educational mode of centralization system, students seldom discuss the democratic political issues with others. A schematic of the main categorical structure in the research is shown in Table 3.This interview was subtitled 'the survey on decision-making of important issues', and investigation results are as follows: 
Table 3: the survey on decision-making of important issues

\begin{tabular}{lllll}
\hline \multicolumn{1}{c}{ decision-makers } & numbers & proportion & Valid decision & $\begin{array}{l}\text { Cumulative } \\
\text { percentages }\end{array}$ \\
\hline The teachers' decision & & & & 96.1 \\
principals' decision & 185 & 31.7 & 31.7 & 94.4 \\
collective decision & 365 & 62.7 & 62.7 & 2.1 \\
no idea & 12 & 2.1 & 2.1 & 3.5 \\
Total value & 20 & 3.4 & 3.5 & 100.0 \\
missing value & 582 & 100.0 & 0 & \\
Total respondents & 0 & 0 & 0 & \\
\hline
\end{tabular}

4.2.3 The deficient aspects in the democratic education system

Has the teacher education contributed to being able to educate for a democratic society? Results suggest that the present college democratic education is confined to the ideological and theoretical courses. Restricted to the capacity of teaching materials and class hours, what can not be avoided is the insufficient educational content that helps students to understand concepts like social justice, peace and equity (Cekaite, 2007 , p. 46).. As is know to all that democratic education requires the teacher s' ability to handle the processes and content of teaching controversial issues in the classroom particularly in this personal -ism age. However, the cultivation of democratic consciousness still stands on the infusion education stage without personal awareness. A survey of over 400 respondents using in questionnaires generally suggests that $20.8 \%$ percent of them point the democratic concept is acquired from theoretical teaching. The others concerned on the current political events by mass media so as to obtain the democratic information accounts for $82.4 \%$. The obviously data demonstrates that the proportion of students approached to democracy by theoretic education is far below the mass media and also reflects the inefficiency of classroom education for college students' democratic infusion.

\section{Discussion}

The phenomenon under inquiry in this study has been the students' perspectives of democracy caring in order to facilitate the construction of an education model of democracy, whereas the above finding of the study was the repeated ability of these caring teachers who is required to interpret and translate diverse principles, motivations of the theoretical textbooks into specific practices for students in class. The introspection of the problems in the democratic construction of university students included:

5.1 The existing problems in the teaching content According to the sociological theory, the acquisition of democratic knowledge belongs to the process of political socialization, which particularly refers to the process of conveying social values and political attitude. Furthermore, an individual political identification towards the country or a certain group is generally formed in its college studying age and the college students' political value and caliber is relates to the future political democratization of China. The politics teaching material, which plays an important role, is a carrier to convey democratic ideology. However, influenced by variable objective ingredients, the boring teaching methods have become a primary issue hidden in the way of higher education reforming process. The present democratic education is infused in terms of the historical investigation or theoretical transmission, divorced from the developing trend of current politics. Provided by the survey, a majority view that' $I$ wonder if there is any use of the polite formula to us in the textbook and I just think it is a waste of time'.(76.0\%) This is to some extent a sense of satire or poignant criticism, but an educational warning worthy of our attention. The present politics education hasn't reached a point regarding democracy as a mode of life relates to personal interests, thus leading to the negative participation behavior.

5.2 The problems existed in the democratic construction system

Democracy and freedom is the current values compatible with the market economy as well as the achievement of civilization acquitted in the long world developing progress. With the development of Chinese economy, not only does the demands for economic reform, so does the political restructuring. To foster the new citizen with democratic awareness is the requirement of national political democratization, for which college is the principal choice. Delightedly, the 30 years' opening and reform has witnessed the achievements on the exploration of socialist political restructuring, whereas some problems unsolved will still be an threaten to the national socialist construction, such as the electoral system, ethnic policy, equality of education, and other factors leading to social instability. Despite of varieties of objective causes to the lagging development in democratic construction, such as the funds shortage or under-investment and the lack of talent, measures must be taken to improve the legal participation in the national economic, political, cultural and other various social affairs. 


\section{Conclusion}

With in this study, the findings of the question asking for actual approaches to improving the democracy quality of the contemporary university students are as follows: Firstly, In terms of the official, the proposal about new policy to be issued on university ideological work. It is well-known that the pioneering ideological work is of great significance to the socialist construction. The strengthening on university students ideological development is a policy relates to Marxism's leading role (Apple, 2004), as well as the training of constructors and successors for socialism with Chinese characteristics. Universities' democratic proceeding is a huge project involved in diversity of aspects, including the students' idea of individual development and equal status in the interaction between teaching and learning .Therefore, it is very important for the college administrators to adapt their old ideas to the rapidly developing situation, such as the accept-ion of the students' dominant position in democratic management and fulfillment of their democratic aspirations. Educators are required to demonstrate their ability to develop 'a critical, ethical and committed political attitude' in their learners, as well as display an appreciation of respect for people of different values, beliefs, practices. (Buzzelli \& Johnston, 2002) University, as a result, can be acted as a service agency aimed at the education of students' physical and psychological health, vocational choice and cultivation of a harmonious social interaction. If formal education becomes one important agency that can help to foster and develop such characteristics ((cf., Jones, 200 6; Westheimer, 1998 ),it is a great contribution to the government's democratic construction as university is an important part of social system and can't be existed independently .The talents produced from universities shall be facilitators and servant to the future socialist building, therefore, there is an absolute necessity for the government's policy to education management. Secondly, In terms of the university education, the administrators should create a democratic lifestyle where students adopted as the citizens being respected. (Rainer \&Guyton, 1999: 122). As it has referred to in this article that the relationship between democracy and education is the analyses of the two conceptions, democracy education and democratic education .The former emphasizes the teaching process of democratic information. The letter stresses the importance of applying democratic principles into practice, which is more functional to obtain the democratic values and behavior. As Gutmann and Thompson(as cited in Englund,2000)once mentioned that in order to make the democracy more deliberate, one of the most important institutions apart from government is the educational system or schools should do whatever possible to prepare their students as citizens (Tholander, 20 07; de Winter, 1997), so when comes to citizens' education, it can be analyzed in two dimensions. The first function is the applied implementation for citizens to internalize the knowledge, skills and values referred to democracy and the other is the functional education being democratic. From these two perspectives, in order to get a deep insight into the democratic culture, what required for the university administrators is not to function democracy as a governing system, but adopt it as a lifestyle giving importance to personal existence as a respected being. Since democracy overemphasis the freedom that people can determine their individual characteristics and difference, ( Karsten,Cogan, Grossman, Liu, \& Pitiyanuwat, 2002; Veugelers, 2011; Geijsel, Ledoux, Reumerman,\& Ten Dam, 2012 ), so it is necessary to inform the school workers to find a balanced point of school's overall goal and student personal development. What is more, the world reality is the challenges and high expectations to improve the teaching quality under a harmonious and democratic environment between the teachers' leadership and classroom management practice ( Cekaite, 2007 , p. 46).Depending on the responsibilities of the administrators on how to achieve a success ,such as creating energy on campus ,building security ,securing a democratic environment ,extending their vision, minimizing the sharp crisis and other practical education effect (cf. Willemse et al., 20 08). Rather than there being a contradiction between the two, Karaman-Kepenekci(2003)once stated that one of the prerequisites of a democratic school is based on love, respect, understanding and tolerance and making decisions altogether with the members of the school. Meanwhile, another scholar once also pointed a democratic educational life can be divided into two democracy education and democratic education. (Kincal\&Isik, 2003). The former is identified as the aim to inform individuals of the awareness and values of equality and justice, but the letter refers to the education through which the principles and rules of democracy and human rights are learned by experience and also emphasizes that the democratic education provides equal rights and opportunities for everyone, so a democratic lifestyle Lawy \& Biesta, 2006) can be achieved with the contribution of every walks of life, including the administrators, teachers and students themselves.Finally, in terms of the electronic information source, the tele-democracy, e-learning, culture interaction that enable the individuals to become lifelong democratic participators.

The dynamic social and economic changes has new requirements for the universities that they should get rid of the traditional teacher-centered and teacher-directed forms of teaching, but enhance the role of education played in cultivation of subjective initiative, creativity and independent judgment(Stoll $\&$ Louis, 2007). A survey investigated in the past to 
search the reasons for democracy failure is the information isolation. Thanks to the contribution of the Internet or other mass media, which makes electronic election and electronic voting system possible. Since the Internet is open not to a certain class or one district, everyone on the earth can be achievable. However, in many societies, democracy is required more because of some reasons, such as the lack of feeling of the citizenship result from the economical and political systems. In order to improve the correlation between the democratic system and the Internet system, to form a culture for education, communication, tolerance, cooperation maybe an effective means to meet these demands. Therefore, one conclusion can be reached---the Internet and other mass media can be an effective means to broadcast the voice of democracy in the future.

\section{References}

1. Acemoglu, Daron, Robinson, James, (2006).The Economic Origins of Dictatorship and Democracy. Cambridge University Press, Cambridge.

2. Apple, M, W. \& Beane, J, A. (2011). Demokratik Okullar (1. bs.). Ankara: Dipnot Yayinlari.

3. Apple, M. W. (2004). Ideology and curriculum ( $3^{\text {rd }}$ ed). New York: Routledge Falmer.

4. Addams, H.\& Woodbury, D.\& Allred, 2010: T. Developing Student Communication Skills while Assisting Nonprofit Organizations. Business Communication Quarterly, (73), 282-290.

5. Bakir, K. (2012). Demokratik Egitim: John Dewey'in Egitim Felsefesi Uzerine (2.bs.). Ankara: Pegem Akademi.

6. Buzzelli, C. A ., \& Johnston, B. (2002).The moral dimensions of teaching: Language, power and culture in classroom interaction. New York: RoutledgeFalmer .

7. Buhl, Monika (2003). Jugend, Familie, Politik. Familiale Bedingungen und politische Orientierungen im Jugendalter. Opladen: Leske und

8. Bergquist, W. H. The Four Cultures of the Academy: Insights and Strategies for Improving Leadership in Collegiate Organization. San Francisco: Jossey-Bass. Inc, 1992.

9. Cekaite, A . (2007). A child's development of interactional competence in a Swedish L2 classroom. The Modern Language Journal, $91,45-61$.

10. Deuchar, R. (2003). Preparing tomorrow's people: the new challenges of citizenship education for involving Scottish pupils and teachers in participative decision-making processes.Scottish Educational Review, 35, 27- 37.

11. Detjen, Joachim (2007). Politische Bildung. Geschichte und Gegenwart in Deutschland. München. Wien: Oldenbourg.

12. Dogan, .(2004). Toplum ve Egitim. (1.bs.). Ankara: PegemA Yayinlari. Starkey, H. (2005) Democratic education and learning. British Journal of Sociology of Education, 26 (2), 299-308, DOI: 10.1080/0142569052000329200.

13. Euridyce. (2005). Citizenship education at school in Europe. Survey. Brussels: Euro-pean Commission.

14. Englund, T. (2006). Deliberative communication: a pragmatist proposal.Journal of Curriculum Studies, 38, 503 -520 .

15. Guille'n, M. F., \& Sua'rez, S. L. (2005). Explaining the global digital divide: economic, political and sociological drivers of cross-national Internet use. Social Forces, 84(2), 681-708.

16. James, A ., Jenk s, C., \& Prout, A . (1998).Theorizing childhood. Cambridge: Polity Press.

17. Jones, K. (Ed.). (2006). Democratic school accountability: A model for school improvement. Lanham: Rowman \& Little field Education.

18. Kincal, R., Y., \& Isik, H. (2003). Demokratik egitim ve demokratik deugtgerler. Egitim Arastirmalari,11, s. 54-58.

19. Karsten, S., Cogan, J. J., Grossman, D. L., Liu, M., \& Pitiyanuwat, S. (2002). Citizenship education and the preparation of future teachers: a study. Asia Pacific Education Review, 3(2), $168-183$.

20. Lawy, R., \& Biesta, G. (2006) . Citizenship-as-practice: the educational implications of an inclusive and relational understanding of citizenship. British Journal of Educational Studies, 54(1), 34 - 50.

21. Leppard, L. J. (1993). Teaching for democratic action in a deliberative democracy. Social Education, 57,78 -80.

22. Rainer, J., \& Guyton, E. (1999). Democratic practice in teacher education and elementary classroom. Teaching and Teacher Education, 15, 121-132.

23. Schou, L. R. (2001). Democracy in education. Studies in Philosophy and Education, 20,317 -329

24. Scott, T. J., \& O'Sullivan, M. (2000). The Internet and information literacy: Taking the first step toward technology education in the social studies. Social Studies, 91(3), 121-125.

25. Sisman, M., Gules, H. \& Donmez, A. (2010). Demokratik bir okul kulturu icin yeterlilikler cercevesi. Usak Universitesi Sosyal Bilimler Dergisi,3 (1), 167-182

26. Sander, Wolfgang (2002). Von der Volksbelehrung zur modernen Profession. Zur Geschichte der politischen Bildung zwischen Ideologie und

27. Wissenschaft. In: Butterwege, Christoph/Hentges, Gudrun (Hrsg.): Politische Bildung und Globalisierung. Opladen: VS Verlag.

28. Stoll, L., \& Louis, K. S. (2007). Professional learning communities: Divergence, depth and dilemmas. Berkshire, UK: Open University Press.

29. Ten Dam, G., \& Volman, M. (2007). Educating for adulthood or for citizenship: social competence as an educational goal.European Journal of Education, 42, 281-298.

30. Tholander, M. (2007). Students' participation and non-participation as a situated accomplishment. Childhood, $14,449-466$.

31. Tsai, C.-C., Lin, S. S. J., \& Tsai, M.-J. (2001). Developing an Internet attitude scale for high school students. Computers and Education, 37, 41-51.

32. Willemse, T. M., Lunenberg, M., \& Korthagen, F. (2008). The moral aspects of

33. teacher educators' practices. Journal of Moral Education, $374,445-466$ 